\title{
A Theoretical Study of 5-methyl-2-isopropylphenol (Thymol) by DFT
}

\author{
Raksha Gupta
}

Department of Chemistry, A. S. (P.G.) College, Mawana, Meerut, India

\begin{abstract}
Article Info

Volume 8, Issue 3

Page Number : 812-830

Publication Issue

May-June-2021

\section{Article History}

Accepted : 12 June 2021

Published : 22 June 2021

Gaussian 09, RevisionA.01, software package was used for the theoretical quantum chemical calculations of 5-methyl-2-isopropylphenol. DFT/B3LYP/6$311 \mathrm{G}(\mathrm{d}, \mathrm{p})$ basis was used to perform geometric optimization and vibrational frequency determination of the molecule. The statistical thermochemical calculations of the molecule were done at DFT/B3LYP/6-311G (d, p) basis set to calculate the standard thermodynamic functions: heat capacity (CV), entropy (S) and Enthalpy (E). Various NLO properties like total dipole moment $(\mu)$, mean linear polarizability $(\alpha)$, anisotropic polarizability $(\Delta \alpha)$, first order polarizability $(\beta)$, and second order hyperpolarizability $(\gamma)$ in terms of $x, y, z$ components were calculated at DFT/B3LYP/6-311G (d, p) basis set for 5methyl-2-isopropylphenol. Mulliken population analysis was also done using the same basis set. Time Dependent DFT (TD-DFT) method using the same basis set was used to compute UV-Visible absorption spectra, ECD spectra, electronic transitions, vertical excitation energies and oscillator strengths of 5methyl-2-isopropylphenol.FMO analysis, ESP study were also done using the same basis set.

Keywords : DFT, FMO, Mulliken population analysis, TD-DFT, NLO properties, ECD, Global reactive descriptors
\end{abstract}

\section{INTRODUCTION}

Thymol, a natural monoterpenoid phenol, also known by the chemical names 2-isopropyl-5-methylphenol and 5-methyl-2-isopropylphenol in accordance with International Union of Pure and Applied Chemistry (IUPAC), is crystalline and colourless with a characteristic odour. The structural formula of this compound is shown in Fig. 1.<smiles>Cc1ccc(C(C)C)c(O)c1</smiles>

Figure 1: Structural formula of 5-methyl-2isopropylphenol 
Thymol isomeric with carvacrol is abundantly found in certain plants such as Thymus vulgaris[1], Ocimum gratissimum [2], Thymus ciliates [3], Satureja thymbra [4], Thymus zygis [5], Trachyspermum ammi [6], Carum [7], Thymbra capitata [8] etc.

Thymol, a white crystalline solid has density 0.96 $\mathrm{g} / \mathrm{cm}^{3}$ at $25^{\circ} \mathrm{C}$ with a melting point ranging from $49^{\circ} \mathrm{C}$ to $51^{\circ} \mathrm{C}$ [9]. It is highly soluble in alcohol, alkaline solutions and other organic solvents due to deprotonation of phenol but is slightly soluble in water at neutral $\mathrm{pH}$ and it absorbs maximum UV radiation at $274 \mathrm{~nm}[10-11]$.

Thymol has been known to possess biological activities like antiseptic, antibacterial, antifungal, anthelmintic, antiviral, antioxidant, expectorant, antispasmodic, carminative, diaphoretic, sedative, anti-rheumatic, and even anti-cancer, antihyperlipidemic and anti-hyperglycaemic action [12-19]. Thymol and its derivatives have been evaluated for quantitative structure -activity relationship to predict the biological activity [20].

Thymol is an important agent of natural origin and has generated interest in scientific community throughout the world for its new biological and pharmacology activities. This motivated us to carry out computational study of this compound. The computation of the geometry and electronic properties presented here are very helpful in understanding the structure-activity relationship of this compound.

\section{MATERIALS AND METHODS}

All theoretical calculations of 5-methyl-2isopropylphenol as depicted by graphical abstract in Fig. 2 have been performed using personal laptop using Gaussian 09, Revision A. 01 software package [21] and Gauss View 6.0 programme. DFT (Density Functional Theory), and the Becke three-parameter exchange functions in combination with the LYP correlation function of the Lee, Yang and Parr (B3LYP) method were used for the theoretical study of 5-methyl-2-isopropylphenol. DFT/B3LYP/6-311G $(\mathrm{d}, \mathrm{p})$ basis set was used for determining geometrical optimizations and vibrational frequency of the molecule. Time Dependent DFT (TD-DFT) method using the same basis sets was used to compute the Simulated UV-Visible absorption spectra, oscillator strengths, vertical excitation energies and electronic transitions of the same molecule.

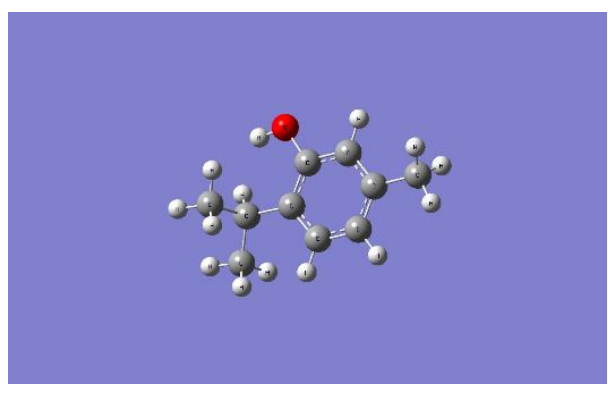

Figure 2: Graphical Abstract of 5-methyl-2isopropylphenol

\section{RESULTS AND DISCUSSION}

\section{Geometrical analysis}

5-methyl-2-isopropylphenol commonly called Thymol having empirical formula $\mathrm{C}_{10} \mathrm{H}_{14} \mathrm{O}$, Molecular mass:150.10447 amu, is an asymmetric top type of molecule with 69 degrees of freedom. The optimised molecular structure of the molecule under consideration i.e., 5-methyl-2-isopropylphenol is obtained from Gaussian 09, Revision A. 01, and Gauss view 6.0 programme with the numbering scheme of atoms as shown in Fig. 3. The optimised geometrical parameters (bond length, bond angle and dihedral angle) calculated by B3LYP/6-311G (d, p) level basis set are listed in Table 1.

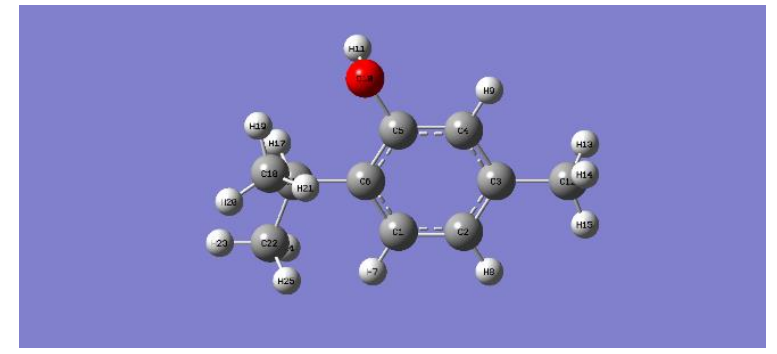

Figure 3: Optimised Molecular structure of 5-methyl2-isopropylphenol 
Raksha Gupta Int J Sci Res Sci \& Technol. May-June-2021, 8 (3) : 812-830

Table 1: The optimised geometrical parameters (bond length, bond angle and dihedral angle) of 5-methyl-2isopropyl phenol as calculated by B3LYP/6-311G (d,p) level basis set

\begin{tabular}{|c|c|c|c|c|c|c|}
\hline S. No. & $\begin{array}{l}\text { Bond } \\
\text { between } \\
\text { atoms }\end{array}$ & $\begin{array}{l}\text { Bond } \\
\text { length(§) }\end{array}$ & $\begin{array}{l}\text { Bond angle } \\
\text { between atoms }\end{array}$ & Bond angle $\left(^{\circ}\right)$ & $\begin{array}{l}\text { Dihedral angle } \\
\text { between atoms }\end{array}$ & $\begin{array}{l}\text { Dihedral } \\
\text { angle }\left(^{(}\right)\end{array}$ \\
\hline 1 & $\mathrm{R}(1,2)$ & 1.3944 & $\mathrm{~A}(2,1,6)$ & 122.222 & $\mathrm{D}(6,1,2,3)$ & -0.2158 \\
\hline 2 & $\mathrm{R}(1,6)$ & 1.3973 & $\mathrm{~A}(2,1,7)$ & 118.5813 & $\mathrm{D}(6,1,2,8)$ & 179.8521 \\
\hline 3 & $\mathrm{R}(1,7)$ & 1.0835 & $\mathrm{~A}(6,1,7)$ & 119.1966 & $\mathrm{D}(7,1,2,3)$ & 179.8447 \\
\hline 4 & $\mathrm{R}(2,3)$ & 1.3969 & $\mathrm{~A}(1,2,3)$ & 120.5507 & $\mathrm{D}(7,1,2,8)$ & -0.0874 \\
\hline 5 & $\mathrm{R}(2,8)$ & 1.0847 & $\mathrm{~A}(1,2,8)$ & 119.6073 & $\mathrm{D}(2,1,6,5)$ & 0.0805 \\
\hline 6 & $\mathrm{R}(3,4)$ & 1.3965 & $\mathrm{~A}(3,2,8)$ & 119.842 & $\mathrm{D}(2,1,6,16)$ & -177.803 \\
\hline 7 & $\mathrm{R}(3,12)$ & 1.5101 & $\mathrm{~A}(2,3,4)$ & 118.0216 & $\mathrm{D}(7,1,6,5)$ & -179.9804 \\
\hline 8 & $\mathrm{R}(4,5)$ & 1.3939 & $\mathrm{~A}(2,3,12)$ & 121.5052 & $\mathrm{D}(7,1,6,16)$ & 2.1361 \\
\hline 9 & $\mathrm{R}(4,9)$ & 1.0851 & $\mathrm{~A}(4,3,12)$ & 120.468 & $\mathrm{D}(1,2,3,4)$ & 0.0899 \\
\hline 10 & $\mathrm{R}(5,6)$ & 1.409 & $\mathrm{~A}(3,4,5)$ & 121.1895 & $\mathrm{D}(1,2,3,12)$ & -179.0809 \\
\hline 11 & $\mathrm{R}(5,10)$ & 1.3724 & $\mathrm{~A}(3,4,9)$ & 120.7266 & $\mathrm{D}(8,2,3,4)$ & -179.9782 \\
\hline 12 & $\mathrm{R}(6,16)$ & 1.5248 & $\mathrm{~A}(5,4,9)$ & 118.0838 & $\mathrm{D}(8,2,3,12)$ & 0.851 \\
\hline 13 & $\mathrm{R}(10,11)$ & 0.9634 & $\mathrm{~A}(4,5,6)$ & 121.3213 & $\mathrm{D}(2,3,4,5)$ & 0.1642 \\
\hline 14 & $\mathrm{R}(12,13)$ & 1.095 & $\mathrm{~A}(4,5,10)$ & 116.0158 & $\mathrm{D}(2,3,4,9)$ & -179.8879 \\
\hline 15 & $\mathrm{R}(12,14)$ & 1.0936 & $\mathrm{~A}(6,5,10)$ & 122.6604 & $\mathrm{D}(12,3,4,5)$ & 179.3439 \\
\hline 16 & $\mathrm{R}(12,15)$ & 1.0916 & $\mathrm{~A}(1,6,5)$ & 116.6941 & $\mathrm{D}(12,3,4,9)$ & -0.7081 \\
\hline 17 & $\mathrm{R}(16,17)$ & 1.0999 & $\mathrm{~A}(1,6,16)$ & 122.7654 & $\mathrm{D}(2,3,12,13)$ & 109.4264 \\
\hline 18 & $\mathrm{R}(16,18)$ & 1.5439 & $\mathrm{~A}(5,6,16)$ & 120.5064 & $\mathrm{D}(2,3,12,14)$ & -131.3191 \\
\hline 19 & $\mathrm{R}(16,22)$ & 1.5349 & $\mathrm{~A}(5,10,11)$ & 110.0982 & $\mathrm{D}(2,3,12,15)$ & -10.6066 \\
\hline 20 & $\mathrm{R}(18,19)$ & 1.093 & $\mathrm{~A}(3,12,13)$ & 111.0946 & $\mathrm{D}(4,3,12,13)$ & -69.7243 \\
\hline 21 & $\mathrm{R}(18,20)$ & 1.0937 & $\mathrm{~A}(3,12,14)$ & 111.3282 & $\mathrm{D}(4,3,12,14)$ & 49.5302 \\
\hline 22 & $\mathrm{R}(18,21)$ & 1.0938 & $\mathrm{~A}(3,12,15)$ & 111.2481 & $\mathrm{D}(4,3,12,15)$ & 170.2426 \\
\hline 23 & $\mathrm{R}(22,23)$ & 1.0929 & $\mathrm{~A}(13,12,14)$ & 107.0864 & $\mathrm{D}(3,4,5,6)$ & -0.3036 \\
\hline 24 & $\mathrm{R}(22,24)$ & 1.0928 & $\mathrm{~A}(13,12,15)$ & 107.7451 & $\mathrm{D}(3,4,5,10)$ & 179.1331 \\
\hline 25 & $\mathrm{R}(22,25)$ & 1.0934 & $\mathrm{~A}(14,12,15)$ & 108.1556 & $\mathrm{D}(9,4,5,6)$ & 179.7471 \\
\hline 26 & & & $\mathrm{~A}(6,16,17)$ & 107.8209 & $\mathrm{D}(9,4,5,10)$ & -0.8161 \\
\hline 27 & & & $\mathrm{~A}(6,16,18)$ & 110.9679 & $\mathrm{D}(4,5,6,1)$ & 0.1759 \\
\hline 28 & & & $\mathrm{~A}(6,16,22)$ & 113.9318 & $\mathrm{D}(4,5,6,16)$ & 178.1102 \\
\hline 29 & & & $\mathrm{~A}(17,16,18)$ & 107.5539 & $\mathrm{D}(10,5,6,1)$ & -179.2229 \\
\hline 30 & & & $\mathrm{~A}(17,16,22)$ & 105.6424 & $\mathrm{D}(10,5,6,16)$ & -1.2885 \\
\hline 31 & & & $\mathrm{~A}(18,16,22)$ & 110.5516 & $\mathrm{D}(4,5,10,11)$ & 173.573 \\
\hline 32 & & & $\mathrm{~A}(16,18,19)$ & 111.7492 & $\mathrm{D}(6,5,10,11)$ & -6.9986 \\
\hline 33 & & & $\mathrm{~A}(16,18,20)$ & 110.7198 & $\mathrm{D}(1,6,16,17)$ & -143.5051 \\
\hline 34 & & & $\mathrm{~A}(16,18,21)$ & 110.2091 & $\mathrm{D}(1,6,16,18)$ & 98.9487 \\
\hline 35 & & & $\mathrm{~A}(19,18,20)$ & 108.0161 & $\mathrm{D}(1,6,16,22)$ & -26.5991 \\
\hline 36 & & & $\mathrm{~A}(19,18,21)$ & 107.8006 & $\mathrm{D}(5,6,16,17)$ & 38.6896 \\
\hline 37 & & & $\mathrm{~A}(20,18,21)$ & 108.2209 & $\mathrm{D}(5,6,16,18)$ & -78.8566 \\
\hline 38 & & & $\mathrm{~A}(16,22,23)$ & 109.7996 & $\mathrm{D}(5,6,16,22)$ & 155.5957 \\
\hline 39 & & & $\mathrm{~A}(16,22,24)$ & 111.5833 & $\mathrm{D}(6,16,18,19)$ & 55.5012 \\
\hline 40 & & & $\mathrm{~A}(16,22,25)$ & 111.6222 & $\mathrm{D}(6,16,18,20)$ & 175.9601 \\
\hline 41 & & & $\mathrm{~A}(23,22,24)$ & 108.1172 & $\mathrm{D}(6,16,18,21)$ & -64.3388 \\
\hline 42 & & & $\mathrm{~A}(23,22,25)$ & 107.3555 & $\mathrm{D}(17,16,18,19)$ & -62.2077 \\
\hline 43 & & & $\mathrm{~A}(24,22,25)$ & 108.2055 & $\mathrm{D}(17,16,18,20)$ & 58.2512 \\
\hline 44 & & & & & $\mathrm{D}(17,16,18,21)$ & 177.9524 \\
\hline
\end{tabular}




\begin{tabular}{|l|l|l|l|l|l|l|}
\hline 45 & & & & & $\mathrm{D}(22,16,18,19)$ & -177.0814 \\
\hline 46 & & & & & $\mathrm{D}(22,16,18,20)$ & -56.6225 \\
\hline 47 & & & & & $\mathrm{D}(22,16,18,21)$ & 63.0786 \\
\hline 48 & & & & & $\mathrm{D}(6,16,22,23)$ & -173.1717 \\
\hline 49 & & & & & $\mathrm{D}(6,16,22,24)$ & -53.3145 \\
\hline 50 & & & & & $\mathrm{D}(6,16,22,25)$ & 67.8983 \\
\hline 51 & & & & & $\mathrm{D}(17,16,22,23)$ & -55.0092 \\
\hline 52 & & & & & $\mathrm{D}(17,16,22,24)$ & 64.8479 \\
\hline 53 & & & & & $\mathrm{D}(17,16,22,25)$ & -173.9392 \\
\hline 54 & & & & & $\mathrm{D}(18,16,22,23)$ & 61.0606 \\
\hline 55 & & & & & $\mathrm{D}(18,16,22,24)$ & -179.0822 \\
\hline 56 & & & & & $\mathrm{D}(18,16,22,25)$ & -57.8694 \\
\hline
\end{tabular}

\section{Vibrational analysis}

The fundamental vibration of a non-linear molecule which contains $\mathrm{N}$ atoms is equal to ( $3 \mathrm{~N}-6)$, apart from three translational and three rotational degrees of freedom [22-24]. 5-methyl-2-isopropylphenol, molecule being studied belongs to asymmetric top group symmetry and has 25 atoms; hence normal modes of vibrations possible are 69. As mentioned above, IR and Raman vibrational properties of the molecule has been studied using B3LYP by DFT at 6311G ( $\mathrm{d}, \mathrm{p}$ ) basis level set and the theoretical IR and Raman spectra are as shown in Fig. 4 and Fig. 5 respectively while the frequencies, intensities and their corresponding assignments for the theoretical spectra are tabulated in Table 2. Animations generated for various vibrational modes by Gauss view 6.0 program were inspected visually and the standard values $[22,24]$ reported were used for vibrational assignment. A comprehensive account of characteristic group absorptions and their relationship to molecular structure is discussed below.

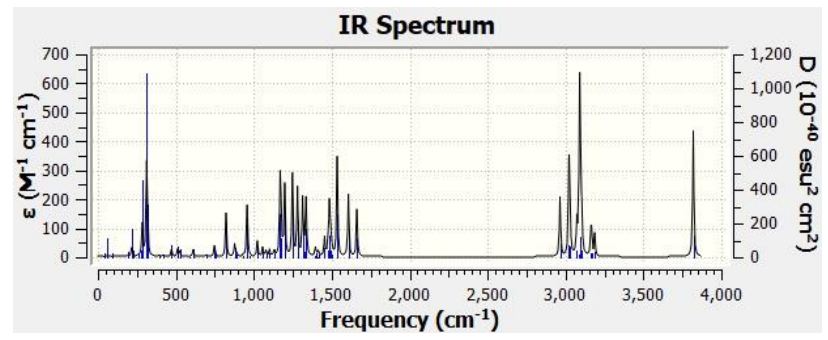

Figure 4: Theoretical IR spectra of 5-methyl-2isopropylphenol

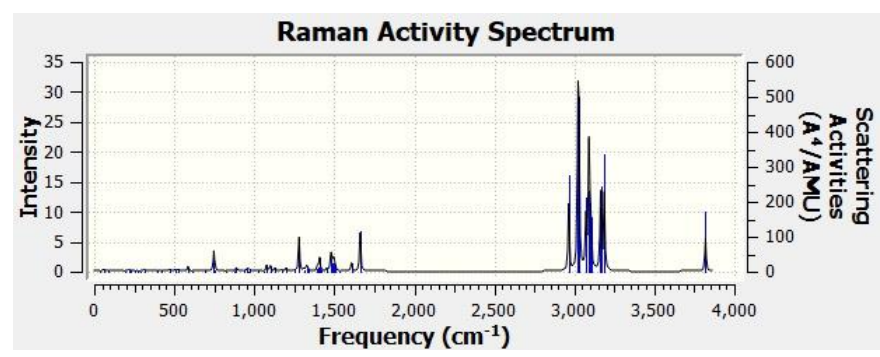

Figure 5: Theoretical Raman spectra of 5-methyl-2isopropylphenol

Table 2 : The frequencies, intensities, and their corresponding assignments for the theoretical IR and Raman spectra of 5-methyl-2-isopropylphenol

\begin{tabular}{|l|l|l|l|l|l|l|}
\hline Mode & Frequency & Infrared & Raman & Depolar-p & Depolar-u & Vibrational assignment \\
\hline 1 & 38.90 & 0.2085 & 0.8584 & 0.7492 & 0.8567 & \\
\hline 2 & 61.43 & 1.7192 & 5.4622 & 0.7481 & 0.8559 & \\
\hline 3 & 91.54 & 0.5501 & 2.6675 & 0.7500 & 0.8571 & \\
\hline 4 & 189.39 & 1.4255 & 0.5472 & 0.7500 & 0.8571 & \\
\hline 5 & 216.28 & 8.9079 & 4.1968 & 0.7460 & 0.8545 & \\
\hline 6 & 223.79 & 2.2296 & 3.9680 & 0.7317 & 0.8450 & \\
\hline 7 & 256.34 & 1.3721 & 0.2963 & 0.7095 & 0.8301 & \\
\hline 8 & 274.81 & 2.6993 & 0.5131 & 0.2617 & 0.4149 & \\
\hline
\end{tabular}


Raksha Gupta Int J Sci Res Sci \& Technol. May-June-2021, 8 (3) : 812-830

\begin{tabular}{|c|c|c|c|c|c|c|}
\hline 9 & 285.16 & 32.3954 & 0.6556 & 0.3993 & 0.5707 & \\
\hline 10 & 312.72 & 85.4998 & 4.8230 & 0.5138 & 0.6788 & Aromatic ring vibration \\
\hline 11 & 317.43 & 25.0248 & 2.1408 & 0.4964 & 0.6634 & Aromatic ring vibration \\
\hline 12 & 394.36 & 1.0524 & 2.1799 & 0.6146 & 0.7613 & Aromatic ring vibration \\
\hline 13 & 421.26 & 1.7815 & 2.3755 & 0.1415 & 0.2479 & Aromatic ring vibration \\
\hline 14 & 472.32 & 8.0745 & 5.3152 & 0.5624 & 0.7199 & Aromatic ring vibration \\
\hline 15 & 510.58 & 7.7859 & 4.6722 & 0.4838 & 0.6521 & Aromatic ring vibration \\
\hline 16 & 524.63 & 6.1153 & 5.4781 & 0.2328 & 0.3777 & Aromatic ring vibration \\
\hline 17 & 584.56 & 0.4888 & 12.2919 & 0.5842 & 0.7375 & Aromatic ring vibration \\
\hline 18 & 610.90 & 7.6024 & 0.5634 & 0.5796 & 0.7339 & Aromatic ring vibration \\
\hline 19 & 692.95 & 2.4461 & 3.4089 & 0.1530 & 0.2654 & Out-of-plane C-H vibrations(oops) \\
\hline 20 & 747.74 & 10.5073 & 49.3936 & 0.1060 & 0.1917 & Out-of-plane C-H vibrations(oops) \\
\hline 21 & 752.11 & 2.8109 & 5.0422 & 0.1040 & 0.1884 & Out-of-plane C-H vibrations(oops) \\
\hline 22 & 821.79 & 43.2679 & 0.5073 & 0.1229 & 0.2190 & $\mathrm{C}-\mathrm{H}$ out-of-plane wagging of $-\mathrm{CH}_{2}$ group \\
\hline 23 & 877.17 & 12.9555 & 0.4383 & 0.7179 & 0.8358 & $\mathrm{C}-\mathrm{H}$ out-of-plane wagging of $-\mathrm{CH}_{3}$ group \\
\hline 24 & 887.87 & 3.5630 & 10.7279 & 0.4186 & 0.5902 & $\begin{array}{l}\text { Out-of-plane rocking of }-\mathrm{CH}_{3} \text { of isopropyl } \\
\text { group }\end{array}$ \\
\hline 25 & 933.28 & 2.0970 & 2.6849 & 0.7210 & 0.8379 & $\begin{array}{l}\text { Out-of-plane rocking of }-\mathrm{CH}_{3} \text { of isopropyl } \\
\text { group }\end{array}$ \\
\hline 26 & 957.03 & 45.6497 & 7.8061 & 0.1668 & 0.2859 & Aromatic ring vibrations (oops) \\
\hline 27 & 959.70 & 9.1272 & 1.8362 & 0.1578 & 0.2727 & Aromatic ring vibrations (oops) \\
\hline 28 & 969.04 & 1.4070 & 6.5027 & 0.7497 & 0.8569 & $\begin{array}{l}\text { Out-of-plane rocking of }-\mathrm{CH}_{3} \text { of isopropyl } \\
\text { substituent }\end{array}$ \\
\hline 29 & 1022.30 & 16.1965 & 3.5302 & 0.3729 & 0.5433 & Aromatic ring vibrations \\
\hline 30 & 1056.71 & 9.2063 & 0.5030 & 0.5777 & 0.7323 & $\begin{array}{l}\text { In-plane } \mathrm{C}-\mathrm{H} \text { bending of }-\mathrm{CH}_{3} \text { group present at } \\
\text { meta position }\end{array}$ \\
\hline 31 & 1077.92 & 6.4216 & 17.7909 & 0.2328 & 0.3776 & $\begin{array}{l}\text { In-plane } \mathrm{C}-\mathrm{H} \text { bending of }-\mathrm{CH}_{3} \text { group of } \\
\text { isopropyl group substituent }\end{array}$ \\
\hline 32 & 1101.08 & 7.5154 & 15.8172 & 0.0877 & 0.1612 & $\begin{array}{l}\text { Out-of-plane } \mathrm{C}-\mathrm{H} \text { bending of }-\mathrm{CH}_{3} \text { group of } \\
\text { isopropyl group present at meta position }\end{array}$ \\
\hline 33 & 1131.32 & 5.9663 & 10.3369 & 0.7466 & 0.8549 & In-plane C-H bending of aromatic ring \\
\hline 34 & 1169.25 & 74.7816 & 4.5245 & 0.3516 & 0.5203 & In-plane O-H bending of phenolic group \\
\hline 35 & 1175.25 & 33.3199 & 3.0005 & 0.7234 & 0.8395 & Out -of--plane C-H bending of Aromatic ring \\
\hline 36 & 1198.46 & 71.3548 & 10.5743 & 0.2562 & 0.4079 & In-of-plane C-H bending of Aromatic ring \\
\hline 37 & 1247.72 & 82.4735 & 2.9960 & 0.7409 & 0.8512 & In-plane C-H bending of Aromatic ring \\
\hline 38 & 1280.19 & 68.3635 & 95.1323 & 0.0916 & 0.1678 & Out-of-plane $\mathrm{C}-\mathrm{H}$ bending of Aromatic ring \\
\hline 39 & 1313.24 & 57.7196 & 5.4522 & 0.7328 & 0.8458 & Out-of-plane $\mathrm{C}-\mathrm{H}$ bending of Aromatic ring \\
\hline 40 & 1327.38 & 9.6502 & 15.7383 & 0.4697 & 0.6391 & In-plane C-H bending of Aromatic ring \\
\hline 41 & 1335.63 & 56.5284 & 9.1927 & 0.5668 & 0.7235 & Out-of-plane $\mathrm{C}-\mathrm{H}$ bending of Aromatic ring \\
\hline 42 & 1392.98 & 2.6977 & 6.7572 & 0.7345 & 0.8470 & $\begin{array}{l}\text { Out -of--plane C-H Bending of - } \mathrm{CH}_{2} \text { of } \\
\text { isopropyl group }\end{array}$ \\
\hline 43 & 1396.31 & 7.8239 & 12.0548 & 0.6373 & 0.7785 & $\begin{array}{l}\text { In-plane } \mathrm{C} \text {-H Bending of }-\mathrm{CH}_{2} \text { of isopropyl } \\
\text { group }\end{array}$ \\
\hline 44 & 1408.32 & 0.9693 & 38.0529 & 0.4365 & 0.6077 & $-\mathrm{CH}_{3}$ group symmetric bending \\
\hline 45 & 1413.72 & 5.5573 & 2.9271 & 0.3384 & 0.5057 & -CH3 group symmetric bending \\
\hline 46 & 1454.28 & 19.2658 & 6.5210 & 0.3177 & 0.4822 & Out -of--plane C-H bending of Aromatic ring \\
\hline 47 & 1477.49 & 13.6625 & 26.6209 & 0.7466 & 0.8549 & $\begin{array}{l}\text { Antisymmetric }-\mathrm{CH}_{3} \text { bending of methyl and } \\
\text { isopropyl substituents }\end{array}$ \\
\hline 48 & 1481.42 & 1.5213 & 34.4875 & 0.7485 & 0.8562 & $\begin{array}{l}\text { Antisymmetric }-\mathrm{CH}_{3} \text { bending of methyl and } \\
\text { isopropyl substituents }\end{array}$ \\
\hline 49 & 1485.14 & 48.3929 & 6.5994 & 0.3421 & 0.5098 & Antisymmetric $-\mathrm{CH}_{3}$ bending of methyl and \\
\hline
\end{tabular}


Raksha Gupta Int J Sci Res Sci \& Technol. May-June-2021, 8 (3) : 812-830

\begin{tabular}{|c|c|c|c|c|c|c|}
\hline & & & & & & isopropyl substituents \\
\hline 50 & 1491.82 & 16.1846 & 22.8425 & 0.6069 & 0.7554 & Antisymmetric $-\mathrm{CH}_{3}$ bending \\
\hline 51 & 1496.38 & 10.2599 & 25.2532 & 0.7408 & 0.8511 & $\mathrm{C}-\mathrm{H}$ waging of $-\mathrm{CH}_{3}$ of isopropyl substituent \\
\hline 52 & 1503.38 & 5.3641 & 18.3050 & 0.6327 & 0.7751 & $\mathrm{C}-\mathrm{H}$ waging of $-\mathrm{CH}_{3}$ of isopropyl substituent \\
\hline 53 & 1535.02 & 99.9613 & 1.0330 & 0.3454 & 0.5135 & $\mathrm{C}=\mathrm{C}$ stretching vibration of benzene ring \\
\hline 54 & 1607.00 & 62.4923 & 25.5243 & 0.6692 & 0.8018 & $\mathrm{C}=\mathrm{C}$ stretching vibration of benzene ring \\
\hline 55 & 1661.25 & 47.5561 & 117.8209 & 0.6009 & 0.7507 & $\mathrm{C}=\mathrm{C}$ stretching vibration of benzene ring \\
\hline 56 & 2964.72 & 59.7300 & 277.5760 & 0.2433 & 0.3914 & C-H stretching of isopropyl group \\
\hline 57 & 3021.52 & 52.2467 & 118.9682 & 0.0245 & 0.0478 & C-H symmetric stretching of -CH3 group \\
\hline 58 & 3023.60 & 48.0440 & 518.0691 & 0.0501 & 0.0954 & $\mathrm{C}-\mathrm{H}$ asymmetrical stretching of $-\mathrm{CH}_{3}$ groups \\
\hline 59 & 3028.85 & 32.9316 & 498.3556 & 0.0063 & 0.0125 & C-H symmetrical stretching of $-\mathrm{CH}_{3}$ groups \\
\hline 60 & 3073.20 & 31.9908 & 213.4689 & 0.7237 & 0.8397 & C-H stretching of $-\mathrm{CH}_{3}$ present at meta position \\
\hline 61 & 3086.83 & 9.7102 & 63.8336 & 0.6758 & 0.8066 & $\begin{array}{l}\text { C-H asymmetric stretching of -methyl group of } \\
\text { isopropyl substituents }\end{array}$ \\
\hline 62 & 3090.60 & 64.6598 & 230.4451 & 0.7041 & 0.8264 & $\begin{array}{l}\text { Symmetrical C-H stretching of methyl groups } \\
\text { of isopropyl substituent }\end{array}$ \\
\hline 63 & 3091.50 & 93.6901 & 227.9133 & 0.6282 & 0.7717 & $\begin{array}{l}\text { Asymmetrical C-H stretching of methyl groups } \\
\text { of isopropyl substituent }\end{array}$ \\
\hline 64 & 3096.72 & 54.1333 & 195.6445 & 0.7410 & 0.8513 & $\begin{array}{l}\text { Symmetrical C-H stretching of methyl groups } \\
\text { of isopropyl substituent }\end{array}$ \\
\hline 65 & 3104.43 & 33.9640 & 157.6080 & 0.7467 & 0.8550 & Symmetrical C-H stretching of methyl group \\
\hline 66 & 3163.63 & 20.4860 & 182.5776 & 0.5804 & 0.7345 & Symmetrical =C-H stretching of aromatic ring \\
\hline 67 & 3167.44 & 19.3639 & 242.8225 & 0.2610 & 0.4140 & Asymmetrical $=\mathrm{C}-\mathrm{H}$ stretching of aromatic ring \\
\hline 68 & 3187.51 & 22.9948 & 334.6880 & 0.2003 & 0.3338 & Symmetrical =C-H stretching of aromatic ring \\
\hline 69 & 3819.89 & 126.2007 & 171.0489 & 0.1814 & 0.3071 & $\begin{array}{l}\text { O-H stretching vibration of non-hydrogen } \\
\text { bonded hydroxyl group of phenol }\end{array}$ \\
\hline
\end{tabular}

\section{1) $\mathrm{C}-\mathrm{H}$ Stretching Vibrations}

Absorption arising from $\mathrm{C}-\mathrm{H}$ stretching in alkanes occur in the general region of $3000-2840 \mathrm{~cm}^{-1}$. In case of methyl group two distinct bands occur at $2962 \mathrm{~cm}^{-1}$ \& $2872 \mathrm{~cm}^{-1}$. Band at $2962 \mathrm{~cm}^{-1}$ results from the asymmetrical(as) stretching mode in which two $\mathrm{C}-\mathrm{H}$ bonds of methyl group are extending while the third one is contracting ( $V_{\text {as }}$ $\mathrm{CH}_{3}$ ). Band at $2872 \mathrm{~cm}^{-1}$ arises from symmetrical (s) stretching $\left(v_{\mathrm{s}} \mathrm{CH}_{3}\right)$ in which all three of $\mathrm{C}-\mathrm{H}$ bonds extend and contract in phase. In case of methylene groups, the asymmetrical stretching $\left(\mathrm{V}_{\mathrm{as}} \mathrm{CH}_{2}\right)$ and (vs $\mathrm{CH}_{2}$ ) occur near 2926 and $2853 \mathrm{~cm}^{-1}$ respectively. $\mathrm{C}-\mathrm{H}$ stretching vibrations due to isopropyl group is very weak and usually lost in other aliphatic $\mathrm{C}-\mathrm{H}$ absorption and is observed near $2890 \mathrm{~cm}^{-1}$.

\section{2) C-H Bending Vibrations}

Two bending vibrations can occur in methyl group-symmetrical bending vibration involving in-phase bending of $\mathrm{C}-\mathrm{H}$ bonds and asymmetrical bending vibration involving out-of-phase bending of $\mathrm{C}-\mathrm{H}$ bonds. The symmetrical bending vibration $\left(\delta_{\mathrm{s}} \mathrm{CH}_{3}\right)$ occurs near $1375 \mathrm{~cm}^{-1}$, the asymmetrical bending vibration $\left(\delta_{\text {as }} \mathrm{CH}_{3}\right)$ near $1450 \mathrm{~cm}^{-1}$. The four bending vibrations are referred to as scissoring, rocking, wagging, and twisting. The band resulting from methylene rocking vibration $\left(\rho \mathrm{CH}_{2}\right)$, appears near $720 \mathrm{~cm}^{-1}$. Configuration in which two methyl groups are attached to the same carbon atoms exhibits distinctive absorption in the $\mathrm{C}-\mathrm{H}$ bending region. A strong doublet with peaks of almost equal intensities at 1385-1380 and 1370$1365 \mathrm{~cm}^{-1}$ are shown by isopropyl group. Weak bands result from methyl rocking vibrations in 
isopropyl group and occur in the range $922-919 \mathrm{~cm}$ 1 .

3) Mononuclear Aromatic Hydrocarbon

Spectra of aromatic compounds show prominent and informative bands in the low frequency range of $900-675 \mathrm{~cm}^{-1}$. Out-of-plane("oop") bending of C$\mathrm{H}$ bonds of aromatic ring results in these strong absorption bands. In-plane bending bands appear in the $1300-1000 \mathrm{~cm}^{-1}$ region. Absorptions in $1600-$ 1585 and $1500-1400 \mathrm{~cm}^{-1}$ regions are due to skeletal vibrations involving carbon-carbon stretching within the aromatic ring. As per the nature of ring constituents, skeletal bands appear as doublets frequently. 3100 and $3000 \mathrm{~cm}^{-1}$ range contain aromatic C-H stretching bands. Weak combination and overtone bands appear in the $2000-1650 \mathrm{~cm}^{-1}$ range.

The in-phase and out-of-plane bending of a ring hydrogen atom is strongly coupled to adjacent hydrogen atoms. The position of absorption of the out-of-plane bending bands is therefore characteristic of the number of adjacent hydrogen atoms on the ring. The bands are frequently intense and appear at $900-675 \mathrm{~cm}^{-1}$.

\section{4) Phenol}

The characteristic bands observed in the spectra of phenols result from $\mathrm{O}-\mathrm{H}$ stretching and $\mathrm{C}-\mathrm{O}$ stretching. These vibrations are sensitive to hydrogen bonding. Strong absorptions in 3700$3584 \mathrm{~cm}^{-1}$ region are due to $\mathrm{O}-\mathrm{H}$ stretching vibration of free hydroxyl group (non-hydrogen bonded hydroxyl group) present in phenol. Due to intermolecular hydrogen bonding additional bands appear at lower frequency, 3550-3200 $\mathrm{cm}^{-1}$. Strong bands in $1260-1000 \mathrm{~cm}^{-1}$ region are due to C-O stretching vibrations in alcohols and phenols. Phenols absorbs at $1390-1330$ and $1260-1180 \mathrm{~cm}^{-1}$. These bands apparently result from interaction between $\mathrm{O}-\mathrm{H}$ bending and $\mathrm{C}-\mathrm{O}$ stretching.

\section{5) $\mathrm{O}-\mathrm{H}$ Bending vibrations}

The $\mathrm{O}-\mathrm{H}$ in-plane bending vibrations occurs in the general region of $1420-1330 \mathrm{~cm}^{-1}$. Out-of-plane bending of bonded $\mathrm{O}-\mathrm{H}$ group in phenols show broad absorption spectra in $769-650 \mathrm{~cm}^{-1}$ region.

\section{Thermochemical properties}

The statistical thermo chemical analysis of 5methyl-2-isopropylphenol is carried out considering the molecule to be at room temperature of $300 \mathrm{~K}$ and one atmospheric pressure. Thermodynamic properties help to understand energetic, structural and reactivity properties of a molecule. Zero-point energies, thermal correction to internal energy, enthalpy, entropy, and heat capacity for a molecular system are computed using frequency calculations and compiled in Table 3a. Thermodynamic stability of the system at given conditions of pressure and temperature are described by these functions. The standard thermodynamic functions: heat capacity $(\mathrm{Cv})$, entropy (S), and enthalpy (E) have been obtained at B3LYP/6-311G (d, p) level and are listed in Table $3 b$.

Table 3a : Thermodynamic Functions computed by frequency calculations of 5-methyl-2isopropylphenol

\begin{tabular}{|l|l|}
\hline & $\begin{array}{l}0.215393 \\
\text { (Hartree/Particle }\end{array}$ \\
Zero-point correction & ) \\
\hline Thermal correction to Energy & 0.227042 \\
\hline $\begin{array}{l}\text { Thermal correction to } \\
\text { Enthalpy }\end{array}$ & 0.227986 \\
\hline $\begin{array}{l}\text { Thermal correction to Gibbs } \\
\text { Free Energy }\end{array}$ & 0.177884 \\
\hline $\begin{array}{l}\text { Sum of electronic and zero- } \\
\text { point Energies }\end{array}$ & -464.643431 \\
\hline $\begin{array}{l}\text { Sum of electronic and } \\
\text { thermal Energies }\end{array}$ & -464.631781 \\
\hline $\begin{array}{l}\text { Sum of electronic and } \\
\text { thermal Enthalpies }\end{array}$ & -464.630837 \\
\hline $\begin{array}{l}\text { Sum of electronic and } \\
\text { thermal Free Energies }\end{array}$ & -464.680939 \\
\hline
\end{tabular}


Table 3b : Thermochemical properties of 5methyl-2- isopropyl phenol as calculated at B3LYP/6-311G(d, p) level.

\begin{tabular}{|c|c|c|c|}
\hline Type & $\begin{array}{l}\mathrm{E} \text { (Thermal) } \\
(\mathrm{kCal} / \mathrm{Mol})\end{array}$ & $\begin{array}{c}\mathrm{Cv} \\
\text { (Cal/Mol- } \\
\text { kelvin) }\end{array}$ & $\begin{array}{c}\text { S (Cal/Mol- } \\
\text { Kelvin) }\end{array}$ \\
\hline Total & 142.471 & 44.258 & 105.449 \\
\hline Electronic & 0.000 & 0.000 & 0.000 \\
\hline Translational & 0.889 & 2.981 & 40.929 \\
\hline Rotational & 0.889 & 2.981 & 30.290 \\
\hline Vibrational & 140.694 & 38.297 & 34.230 \\
\hline Vibration 1 & 0.594 & 1.981 & 5.314 \\
\hline Vibration 2 & 0.597 & 1.973 & 4.411 \\
\hline Vibration 3 & 0.602 & 1.955 & 3.627 \\
\hline Vibration 4 & 0.633 & 1.854 & 2.234 \\
\hline Vibration 5 & 0.645 & 1.816 & 1.990 \\
\hline Vibration 6 & 0.649 & 1.805 & 1.928 \\
\hline Vibration 7 & 0.666 & 1.752 & 1.687 \\
\hline Vibration 8 & 0.677 & 1.720 & 1.566 \\
\hline Vibration 9 & 0.683 & 1.701 & 1.503 \\
\hline Vibration 10 & 0.701 & 1.649 & 1.348 \\
\hline Vibration 11 & 0.704 & 1.640 & 1.323 \\
\hline Vibration 12 & 0.761 & 1.482 & 0.984 \\
\hline Vibration 13 & 0.784 & 1.424 & 0.888 \\
\hline Vibration 14 & 0.829 & 1.311 & 0.731 \\
\hline Vibration 15 & 0.866 & 1.227 & 0.632 \\
\hline Vibration 16 & 0.880 & 1.195 & 0.599 \\
\hline Vibration 17 & 0.942 & 1.065 & 0.477 \\
\hline Vibration 18 & 0.970 & 1.009 & 0.431 \\
\hline
\end{tabular}

\section{Nonlinear optical properties}

Quantum chemical calculations have been very useful for predicting the molecular NLO properties of optically active compounds [25-26]. The relationship between nonlinear optical properties and molecular structure can be better understood with the help of Hyperpolarizability [27]. DFT at B3LYP/-311G(d,p) level was useful in calculating various electric moments like components of electric dipole moment, total dipole moment $(\mu)$, mean linear polarizability $(\alpha)$, anisotropic polarizability $(\Delta \alpha)$, first-order hyperpolarizability $(\beta)$ and second-order hyperpolarizability $(\gamma)$ in terms of $\mathrm{x}, \mathrm{y}, \mathrm{z}$ components by Gaussian 09,
Revision A. 01 package for 5-methyl-2isopropylphenol. The mentioned NLO properties have been calculated by using the Equation 1 to Equation 5 [28-29] and the results are summarized in Table 4.

$$
\begin{aligned}
& \mu=\left(\mu^{2} x+\mu^{2} y+\mu^{2} z\right)^{1 / 2} \\
& \alpha=\frac{1}{3}\left(\alpha_{x x}+\alpha_{y y}+\alpha_{z z}\right) \\
& \Delta \alpha==\frac{1}{\sqrt{2}}\left[\left(\alpha_{\mathrm{xx}}-\alpha_{\mathrm{yy}}\right)^{2}+\left(\alpha_{\mathrm{yy}}-\alpha_{\mathrm{zz}}\right)^{2}+\left(\alpha_{\mathrm{zz}}-\alpha_{\mathrm{xx}}\right)^{2}+\right. \\
& \left.6\left(\alpha_{\mathrm{xy}}^{2}+\alpha_{\mathrm{yz}}^{2}+\alpha_{\mathrm{zx}}^{2}\right)\right]^{1 / 2} \\
& \begin{array}{c}
\beta=\left[\left(\beta_{\mathrm{xxx}}+\beta_{\mathrm{xyy}}+\beta_{\mathrm{xzz}}\right)^{2}+\left(\beta_{\mathrm{yyy}}+\beta_{\mathrm{yzz}}+\beta_{\mathrm{yxx}}\right)^{2}+\left(\beta_{\mathrm{zzz}}+\beta_{\mathrm{zxx}}\right.\right. \\
\left.\left.+\beta_{\mathrm{zyy}}\right)^{2}\right]^{1 / 2}
\end{array} \\
& \gamma=\frac{1}{5}\left[\gamma_{\mathrm{xxxx}}+\gamma_{\mathrm{yyyy}}+\gamma_{\mathrm{zzzz}}+2\left(\gamma_{\mathrm{xxyy}}+\gamma_{\mathrm{xxzz}}+\gamma_{\mathrm{yyzz}}\right)\right]
\end{aligned}
$$

The conversion factor of $\alpha, \beta$ and $\gamma$ in atomic unit are:

1 atomic unit (a.u.) $=0.1482 \times 10^{-24}$ electrostatic unit (esu) for $\alpha$,

1 a.u. $=8.6393 \times 10^{-33}$ esu for $\beta$ and

1a.u. $=5.0367 \times 10^{-40} \mathrm{esu}$ for $\gamma$.

The above function of the molecular system is calculated using B3LY/6-311G (d, p) method, based on (field-independent basis). Urea is one of the prototype molecules and is used as threshold value for comparative study of NLO properties of other molecular systems. The computed electric dipole moment $(\mu)$ of 5-methyl-2-isopropylphenol molecule $(\mu=1.8730 \mathrm{D})$ was calculated to be 0.79 times that of the standard reference material of prototypical molecule urea $(\mu=2.3732 \mathrm{D})$ hyperpolarizability $\beta$ is $1.137671499 \times 10^{-31}$ esu and is about 0.31 times the hyperpolarizability of urea ( $\beta$ of urea $\left.=3.728 \times 10^{-31} \mathrm{esu}\right)$. Thus, it is not recommended to 5-methyl-2-isopropylphenol as a prospective building block for nonlinear optical materials. 
Table 4: Dipole moment $(\mu)$ in Debye, Mean Linear Polarizability $(\alpha)$ in a.u First order Hyperpolarizability $(\beta)$ in au Second order Hyperpolarizability $(\gamma)$ in au as calculated by DFT/B3LYP/6-311G (d, p) for 5-methyl-2isopropylphenol

\begin{tabular}{|c|c|c|c|c|c|c|c|}
\hline \multicolumn{2}{|c|}{$\begin{array}{c}\text { Dipole moment }(\mu) \\
\text { in } \\
\text { Debye }\end{array}$} & \multicolumn{2}{|c|}{$\begin{array}{c}\text { Mean Linear Polarizability }(\alpha) \\
\text { in au }\end{array}$} & \multicolumn{2}{|c|}{$\begin{array}{c}\text { First Order } \\
\text { Hyperpolarizability }(\beta) \text { in au }\end{array}$} & \multicolumn{2}{|c|}{$\begin{array}{c}\text { Second Order } \\
\text { Hyperpolarizability }(\gamma) \text { in au }\end{array}$} \\
\hline$\mu_{\mathrm{x}}$ & -1.6769 & $\alpha_{\mathrm{XX}}$ & -57.7106 & $\beta_{\mathrm{Xxx}}$ & 1.4042 & $\gamma_{\mathrm{XXXX}}$ & -1890.2341 \\
\hline$\mu \mathrm{y}$ & -0.8096 & $\alpha_{Y Y}$ & $\begin{array}{l}-67.8773 \\
\end{array}$ & $\beta_{\mathrm{YYY}}$ & $\begin{array}{l}-4.4913 \\
\end{array}$ & $\gamma_{\mathrm{YYYY}}$ & -636.9377 \\
\hline$\mu \mathrm{z}$ & -0.2022 & $\alpha_{\mathrm{ZZ}}$ & -70.6487 & $\beta_{\mathrm{ZZZ}}$ & -2.9932 & $\gamma_{\text {ZZZZ }}$ & -207.6154 \\
\hline \multirow[t]{14}{*}{ Total $\mu$} & 1.8730 & $\alpha_{X Y}$ & -2.5547 & $\beta_{X Y Y}$ & -4.3134 & $\gamma_{\mathrm{XXXY}}$ & -17.8675 \\
\hline & & $\alpha_{\mathrm{XZ}}$ & 1.5121 & $\beta_{\mathrm{XXY}}$ & 10.1108 & $\gamma_{\mathrm{XxXz}}$ & 10.5098 \\
\hline & & $\alpha_{\mathrm{YZ}}$ & -1.0063 & $\beta \mathrm{xxz}$ & -2.7483 & $\gamma_{Y Y Y X}$ & -24.4633 \\
\hline & & $\begin{array}{c}\text { Total } \\
\alpha\end{array}$ & -65.4122 & $\beta \mathrm{xzz}$ & -3.9644 & $\gamma_{\mathrm{YYYZ}}$ & -9.4711 \\
\hline & & $\Delta \alpha$ & 12.9883 & $\beta_{\mathrm{YZZ}}$ & 4.5786 & $\gamma_{\text {ZZZX }}$ & 2.5585 \\
\hline & & $\alpha$ & $\begin{array}{l}-9.69408804 \times 10^{-24} \\
\text { esu }\end{array}$ & $\beta_{\mathrm{YYZ}}$ & 1.0337 & $\gamma_{\mathrm{ZZZY}}$ & -3.4169 \\
\hline & & & & $\beta_{\mathrm{XYZ}}$ & 1.8956 & $\gamma_{\mathrm{XXYY}}$ & -408.6183 \\
\hline & & & & Total $\beta$ & 13.1685611 & $\gamma_{\mathrm{XxzZ}}$ & -368.9466 \\
\hline & & & & $\beta$ & $1.137671499 \times 10^{-31} \mathrm{esu}$ & $\gamma_{Y Y Z Z}$ & -142.6969 \\
\hline & & & & & & $\gamma_{\mathrm{XXYZ}}$ & -8.9572 \\
\hline & & & & & & $\gamma_{\mathrm{YYXZ}}$ & 7.4024 \\
\hline & & & & & & $\gamma_{\mathrm{ZZXY}}$ & -0.2498 \\
\hline & & & & & & Total $\gamma$ & -915.06216 \\
\hline & & & & & & $\gamma$ & $-4.60889 \times 10^{-37} \mathrm{esu}$ \\
\hline
\end{tabular}

\section{Mulliken population analysis; Mulliken atomic charges}

Quantum chemical calculations play an important role in calculating Mulliken atomic charges [30] of a molecular system. Atomic charges affect dipole moment, polarizability, electronic and other properties of a molecular system. B3LYP method with 6-311G (d, p) basis set was used to calculate Mulliken atomic charges and APT charges of 5-methyl-2-isopropylphenol. Calculated values of Mulliken atomic charges and APT charges are given In Table 5 and plotted in Fig. 6.

Table 5: Mulliken and APT charges on each of the constituent element of 5-methyl-2-isopropylphenol as calculated by B3LYP level with 6-311G (d, p) basis set

\begin{tabular}{|c|c|c|c|}
\hline S. No. & Atom No. & Mulliken Charge & APT Charge \\
\hline 1 & $1 \mathrm{C}$ & -0.086265 & 0.056059 \\
\hline 2 & $2 \mathrm{C}$ & -0.102532 & -0.221343 \\
\hline 3 & $3 \mathrm{C}$ & -0.113402 & 0.196848 \\
\hline 4 & $4 \mathrm{C}$ & -0.087559 & -0.204039 \\
\hline 5 & $5 \mathrm{C}$ & 0.159260 & 0.677394 \\
\hline 6 & $6 \mathrm{C}$ & -0.081965 & -0.147205 \\
\hline
\end{tabular}


Raksha Gupta Int J Sci Res Sci \& Technol. May-June-2021, 8 (3) : 812-830

\begin{tabular}{|c|c|c|c|}
\hline 7 & $7 \mathrm{H}$ & 0.104373 & 0.049160 \\
\hline 8 & $8 \mathrm{H}$ & 0.093818 & 0.023032 \\
\hline 9 & $9 \mathrm{H}$ & 0.096450 & 0.041694 \\
\hline 10 & $10 \mathrm{O}$ & -0.387413 & -0.920362 \\
\hline 11 & $11 \mathrm{H}$ & 0.267701 & 0.381108 \\
\hline 12 & $12 \mathrm{C}$ & -0.258147 & 0.096463 \\
\hline 13 & $13 \mathrm{H}$ & 0.128151 & -0.041277 \\
\hline 14 & $14 \mathrm{H}$ & 0.123893 & -0.032897 \\
\hline 15 & $15 \mathrm{H}$ & 0.114447 & -0.021145 \\
\hline 16 & $16 \mathrm{C}$ & -0.232140 & 0.230320 \\
\hline 17 & $17 \mathrm{H}$ & 0.116926 & -0.109376 \\
\hline 18 & $18 \mathrm{C}$ & -0.242184 & 0.046750 \\
\hline 19 & $19 \mathrm{H}$ & 0.103695 & -0.020181 \\
\hline 20 & $20 \mathrm{H}$ & 0.114720 & -0.050454 \\
\hline 21 & $21 \mathrm{H}$ & 0.110148 & -0.018325 \\
\hline 22 & $22 \mathrm{C}$ & -0.288748 & 0.062434 \\
\hline 23 & $23 \mathrm{H}$ & 0.116600 & -0.031397 \\
\hline 24 & $24 \mathrm{H}$ & 0.117293 & -0.024155 \\
\hline 25 & $25 \mathrm{H}$ & 0.112879 & -0.019107 \\
\hline & & & \\
\hline
\end{tabular}

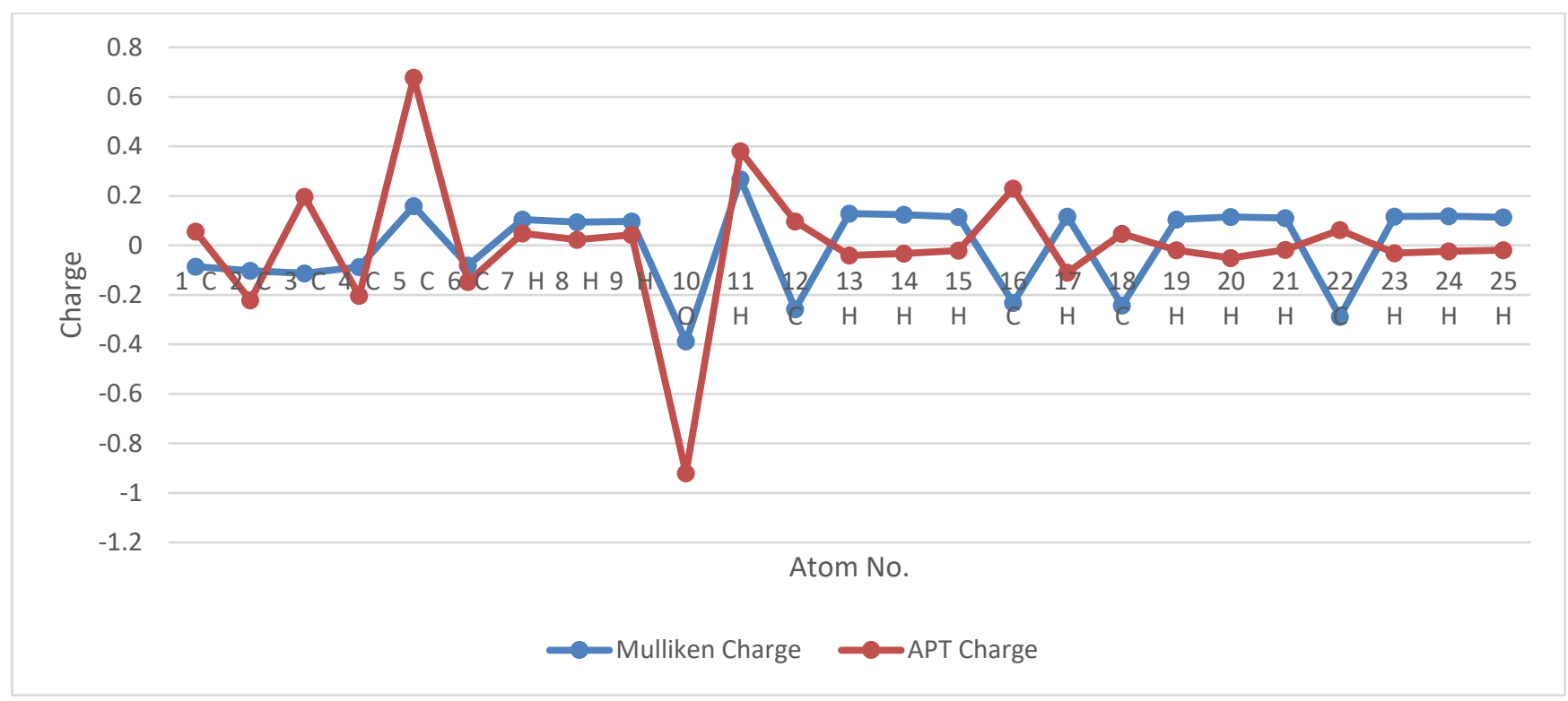

Figure 6: Mulliken and APT Charges on 5-methyl-2-isopropylphenol

For 5-methyl-2-isopropylphenol the Mulliken atomic corresponding charges are 0.267701 and -0.387413 charge of $\mathrm{H}-11$ atom has the maximum positive value respectively.

and becomes highly acidic while O-10 atom has maximum negative charge due to high electronegativity and hence is highly basic. Their 
UV-VISIBLE Spectral Studies and Electronic Properties

TD-DFT calculations facilitates quantum chemists in better understanding of observed electronic absorption spectrum in terms of Excitation energies $(E)$, absorption wavelength $(\lambda)$, oscillator strengths ( $f$ ), molecular orbitals undergoing transitions, transition energy, electronic transitions etc. Molecular orbitals undergoing excitation transition, transition energy and assignments of electronic transitions have been calculated and gathered in Table 6 and the UV Visible spectra of 5-methyl-2-isopropylphenol compound as obtained from TD-DFT calculations is shown in Fig. 7. The electronic transition from HOMO $\rightarrow$ LUMO contribution is represented by absorption wavelength, which implies an electron density transfer as $\pi-\pi^{*}$ transition. Electron excitation from HOMO $\rightarrow$ LUMO describes these electronic absorptions mainly and corresponds to the transition from ground state to the first excited state. The $\lambda_{\max }$, absorption wavelength depends upon the nature of substitution, strong the electron donating character of the substitution, more electrons are pushed into the benzene ring and hence, $\lambda_{\max }$ becomes larger. The $\pi-\pi^{*}$ transitions are expected to occur relatively at lower wavelength i.e., a hypsochromic shift, due to extended aromaticity of the benzene ring. Because of possible electronic transitions in a compound various bands appear in UV-Visible spectra of the molecule under consideration. In the UVVisible spectra of 5-methyl-2-isopropylphenol B-band appears at $237.01 \mathrm{~nm}, \varepsilon_{\max }<100$ and it corresponds to $\pi-\pi^{*}$ transition and is a forbidden band, R-band appears at $209.48 \mathrm{~nm}, \varepsilon_{\max }<1000$ which corresponds to $\mathrm{n}-\pi^{*}$ transition and is also a forbidden band, $\mathrm{K}$ band appears at $193.07 \mathrm{~nm}, \varepsilon_{\max }=2500$ which corresponds to $\pi-\pi^{*}$ transition and is also a forbidden band transition. All the bands are forbidden and that may be due to ISC. Applying the definition of $\mathrm{t}=$ $1.4999 /\left(f E^{2}\right)$, where $E$ is the energy gap of different electronic states in unit of $\mathrm{cm}^{-1}, f$ is the oscillator strength of the electronic state and $t$ is the life-span of this state in the unit of second, the life-span of a particular state can be figured out [31].

Table 6 : Theoretical absorption spectrum of 5-methyl-2-isopropylphenol 1 Excitation energies (E), Absorption wavelength $(\lambda)$ and Oscillator strengths (f)

\begin{tabular}{|c|c|c|c|c|c|c|}
\hline Excited State & $\begin{array}{l}\text { Excitation } \\
\text { Energy(E) }\end{array}$ & $\begin{array}{c}\text { Absorption } \\
\text { Wavelength }(\lambda)\end{array}$ & $\begin{array}{l}\text { Oscillator } \\
\text { Strength }(f)\end{array}$ & $\begin{array}{c}\text { Excitation } \\
\text { Transition } \\
\text { (MO) }\end{array}$ & $\begin{array}{c}\text { Transition } \\
\text { Energy (MO) } \\
\text { Singlet A }\end{array}$ & $\begin{array}{l}\text { Assignment of } \\
\text { electronic } \\
\text { Transitions }\end{array}$ \\
\hline \multirow{2}{*}{1} & \multirow{2}{*}{$5.2311 \mathrm{eV}$} & \multirow{2}{*}{$237.01 \mathrm{~nm}$} & \multirow{2}{*}{0.0155} & $40->43$ & -0.39740 & \multirow{2}{*}{$\pi-\pi^{*}$} \\
\hline & & & & $41->42$ & 0.58296 & \\
\hline \multirow{2}{*}{2} & \multirow{2}{*}{$5.9187 \mathrm{eV}$} & \multirow{2}{*}{$209.48 \mathrm{~nm}$} & \multirow{2}{*}{0.0259} & $40->42$ & 0.45762 & \multirow{2}{*}{$\mathrm{n}-\pi^{*}$} \\
\hline & & & & $41->43$ & 0.53365 & \\
\hline \multirow{4}{*}{3} & \multirow{4}{*}{$6.4218 \mathrm{eV}$} & \multirow{4}{*}{$193.07 \mathrm{~nm}$} & \multirow{4}{*}{0.0541} & $40->43$ & -0.15433 & \multirow{4}{*}{$\pi-\pi^{*}$} \\
\hline & & & & $40->44$ & 0.10236 & \\
\hline & & & & $41->42$ & -0.11525 & \\
\hline & & & & $41->44$ & 0.66485 & \\
\hline
\end{tabular}




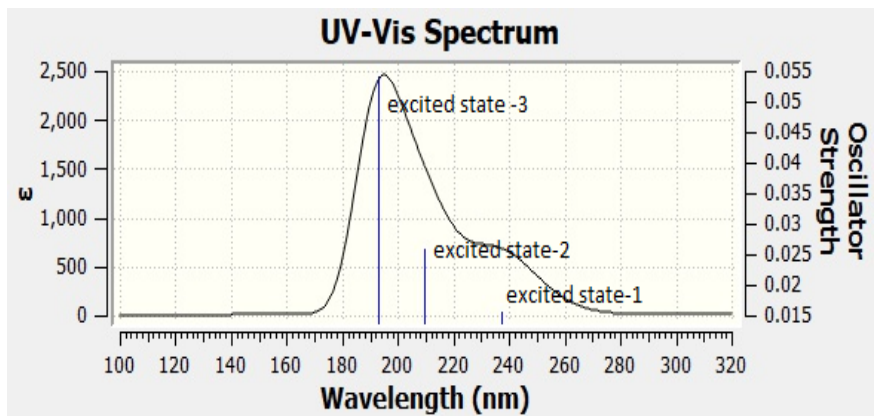

Figure 7: Theoretical UV spectra of 5-methyl-2isopropylphenol

\section{Electronic Circular Dichroism (ECD) spectroscopy}

Electronic circular dichroism (ECD) has been found to be a powerful chiroptical tool for the assignment of absolute configuration of natural products with chromophores since 1960s [32-33]. CD is the phenomena of a chiral molecule that absorbs left and right circularly polarised light beams to different extent. The difference of the absorption is the measure of the magnitude of $\mathrm{CD}$, which is expressed by the differential molar extinction coefficients as $\Delta \varepsilon$ $=\varepsilon 1-\varepsilon_{\mathrm{r}}\left(\mathrm{L} \mathrm{mol}^{-1} \mathrm{~cm}^{-1}\right)$ [34]. TD-DFT method allows the simulation of the ECD spectrum of a medium size molecule on a desktop or PC in a reasonable time [35]. ECD spectra of 5-methyl-2-isopropylphenol was studied using B3LYP/TD-DFT/6-311G (d, p) level and the results are presented in Table-7 and spectra in Fig.

8. In 5-methyl-2-isopropylphenol molecule common chromophore and auxochrome groups are an aromatic ring and a phenolic group. The absorption bands are due to aromatic $\pi-\pi^{*}$ and $\mathrm{n}-\pi^{*}$ transitions. A positive CE at $193.07 \mathrm{~nm}$, $\mathrm{R}_{\mathrm{vel}} 29.99$ corresponds to Rconfiguration while a slightly negative $\mathrm{CE}$ at 209.48nm, $\mathrm{R}_{\mathrm{vel}}-4.93$ corresponds to S-configuration.

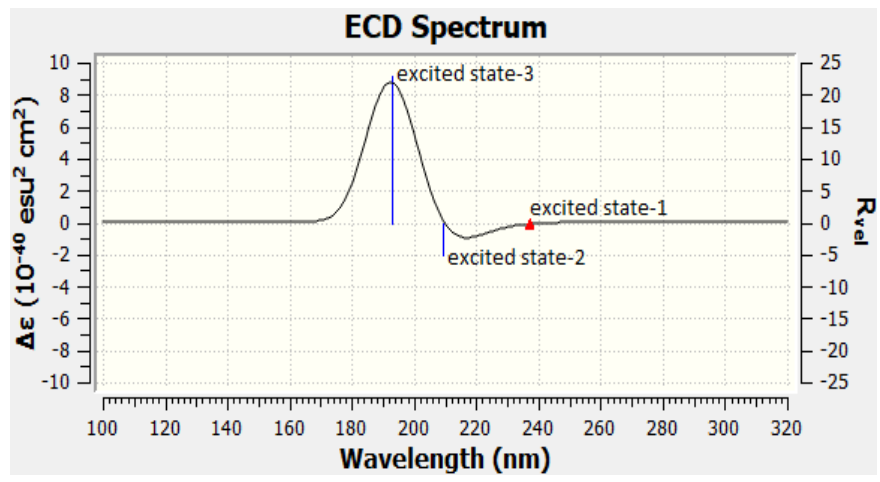

Figure 7: Theoretical UV spectra of 5-methyl-2isopropylphenol

\section{Electronic Circular Dichroism (ECD) spectroscopy}

Electronic circular dichroism (ECD) has been found to be a powerful chiroptical tool for the assignment of absolute configuration of natural products with chromophores since 1960s [32-33]. CD is the phenomena of a chiral molecule that absorbs left and right circularly polarised light beams to different extent. The difference of the absorption is the measure of the magnitude of $C D$, which is expressed by the differential molar extinction coefficients as $\Delta \varepsilon$ $=\varepsilon_{1}-\varepsilon_{\mathrm{r}}\left(\mathrm{L} \mathrm{mol}^{-1} \mathrm{~cm}^{-1}\right)$ [34]. TD-DFT method allows the simulation of the ECD spectrum of a medium size molecule on a desktop or PC in a reasonable time [35]. ECD spectra of 5-methyl-2-isopropylphenol was studied using B3LYP/TD-DFT/6-311G (d, p) level and the results are presented in Table-7 and spectra in Fig. 8. In 5-methyl-2-isopropylphenol molecule common chromophore and auxochrome groups are an aromatic ring and a phenolic group. The absorption bands are due to aromatic $\pi-\pi^{*}$ and $\mathrm{n}-\pi^{*}$ transitions. A positive CE at $193.07 \mathrm{~nm}$, $\mathrm{R}_{\mathrm{vel}} 29.99$ corresponds to $\mathrm{R}$ configuration while a slightly negative $\mathrm{CE}$ at 209.48nm, Rvel -4.93 corresponds to S-configuration. 
Table 6 : Theoretical absorption spectrum of 5-methyl-2-isopropylphenol 1 Excitation energies (E), Absorption wavelength $(\lambda)$ and Oscillator strengths $(f)$

\begin{tabular}{|c|c|c|c|c|c|c|}
\hline Excited State & $\begin{array}{l}\text { Excitation } \\
\text { Energy(E) }\end{array}$ & $\begin{array}{c}\text { Absorption } \\
\text { Wavelength }(\lambda)\end{array}$ & $\begin{array}{c}\text { Oscillator } \\
\text { Strength }(f)\end{array}$ & $\begin{array}{c}\text { Excitation } \\
\text { Transition } \\
\text { (MO) }\end{array}$ & $\begin{array}{c}\text { Transition } \\
\text { Energy (MO) } \\
\text { Singlet A }\end{array}$ & $\begin{array}{l}\text { Assignment of } \\
\text { electronic } \\
\text { Transitions }\end{array}$ \\
\hline \multirow[b]{2}{*}{1} & \multirow{2}{*}{$5.2311 \mathrm{eV}$} & \multirow{2}{*}{$237.01 \mathrm{~nm}$} & \multirow{2}{*}{0.0155} & $40->43$ & -0.39740 & \multirow{2}{*}{$\pi-\pi^{*}$} \\
\hline & & & & $41->42$ & 0.58296 & \\
\hline \multirow{2}{*}{2} & \multirow{2}{*}{$5.9187 \mathrm{eV}$} & \multirow{2}{*}{$209.48 \mathrm{~nm}$} & \multirow{2}{*}{0.0259} & $40->42$ & 0.45762 & \multirow{2}{*}{$\mathrm{n}-\pi^{*}$} \\
\hline & & & & $41->43$ & 0.53365 & \\
\hline \multirow{4}{*}{3} & \multirow{4}{*}{$6.4218 \mathrm{eV}$} & \multirow{4}{*}{$193.07 \mathrm{~nm}$} & \multirow{4}{*}{0.0541} & $40->43$ & -0.15433 & \multirow{4}{*}{$\pi-\pi^{*}$} \\
\hline & & & & $40->44$ & 0.10236 & \\
\hline & & & & $41->42$ & -0.11525 & \\
\hline & & & & $41->44$ & 0.66485 & \\
\hline
\end{tabular}

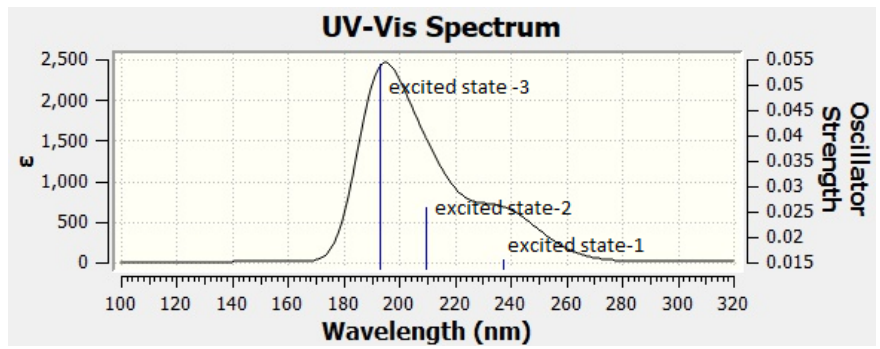

Figure 7: Theoretical UV spectra of 5-methyl-2isopropylphenol

\section{Electronic Circular Dichroism (ECD) spectroscopy}

Electronic circular dichroism (ECD) has been found to be a powerful chiroptical tool for the assignment of absolute configuration of natural products with chromophores since 1960s [32-33]. CD is the phenomena of a chiral molecule that absorbs left and right circularly polarised light beams to different extent. The difference of the absorption is the measure of the magnitude of $\mathrm{CD}$, which is expressed by the differential molar extinction coefficients as $\Delta \varepsilon$ $=\varepsilon 1-\varepsilon_{\mathrm{r}}\left(\mathrm{L} \mathrm{mol}^{-1} \mathrm{~cm}^{-1}\right)$ [34]. TD-DFT method allows the simulation of the ECD spectrum of a medium size molecule on a desktop or PC in a reasonable time [35]. ECD spectra of 5-methyl-2-isopropylphenol was studied using B3LYP/TD-DFT/6-311G (d, p) level and the results are presented in Table-7 and spectra in Fig. 8. In 5-methyl-2-isopropylphenol molecule common chromophore and auxochrome groups are an aromatic ring and a phenolic group. The absorption bands are due to aromatic $\pi-\pi^{*}$ and $n-\pi^{*}$ transitions. A positive CE at $193.07 \mathrm{~nm}$, $\mathrm{R}_{\text {vel }} 29.99$ corresponds to $R$ configuration while a slightly negative $\mathrm{CE}$ at 209.48nm, Rvel -4.93 corresponds to S-configuration.

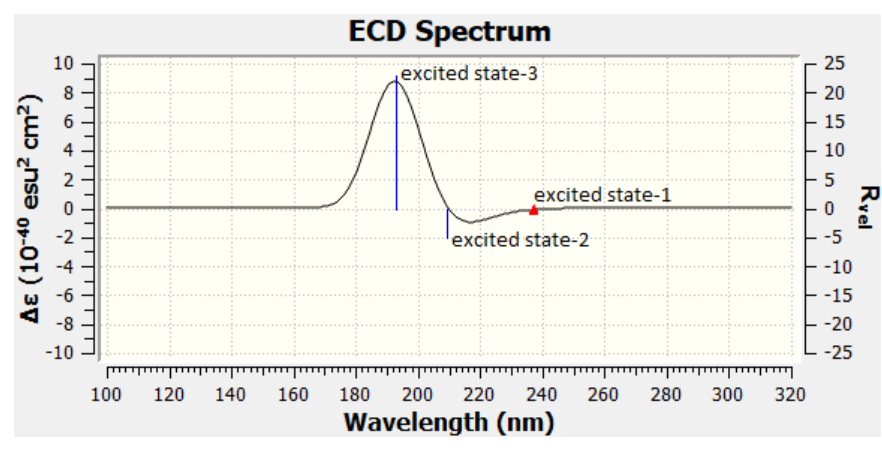

Figure 8 : Theoretical ECD spectra of 5-methyl-2isopropylphenol

Table 7 : ECD spectral results of 5-methyl-2isopropylphenol

\begin{tabular}{|c|c|c|c|}
\hline $\begin{array}{l}\text { Excited } \\
\text { State }\end{array}$ & $\begin{array}{l}\text { Wavelength } \\
(\mathrm{nm})\end{array}$ & $\mathbf{R}_{\text {vel }}$ & $\begin{array}{l}\Delta \varepsilon\left(10^{-40}\right. \\
\mathrm{esu}^{2} \\
\left.\mathrm{~cm}^{2}\right)\end{array}$ \\
\hline 1 & 237.01349 & -0.159491593 & $\approx 0$ \\
\hline 2 & 209.4804273 & -4.943140792 & $\approx 0.2$ \\
\hline 3 & 193.0679243 & 22.98588495 & $\approx 9$ \\
\hline
\end{tabular}




\section{Frontier Molecular Orbital (FMO) Analysis}
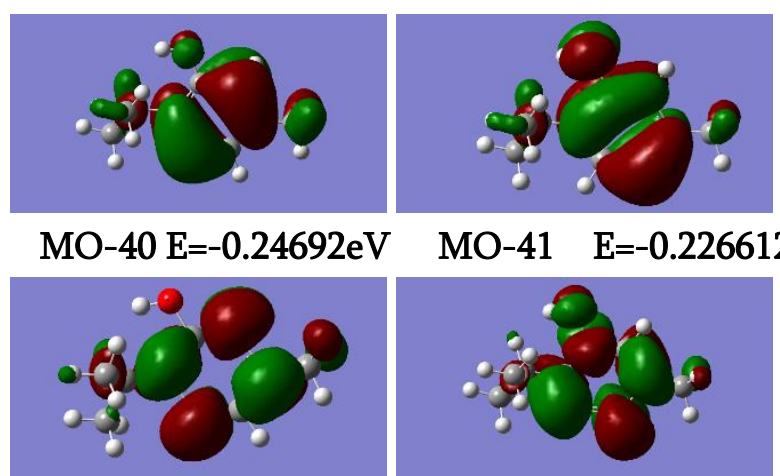

$\mathrm{MO}-42 \mathrm{E}=-0.01182 \mathrm{eV}$
MO-41 $\mathrm{E}=-0.226612 \mathrm{eV}$

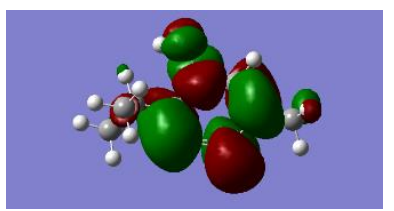

MO-43 E= $0.00368 \mathrm{eV}$

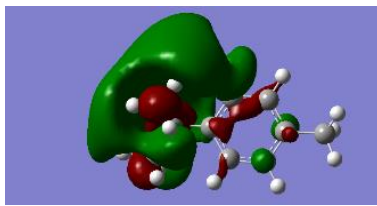

$\mathrm{MO}-44 \quad \mathrm{E}=0.03532 \mathrm{eV}$

Figure 9: FMO analysis Result

Interaction of two atomic orbitals with each other produces two new orbitals called molecular orbitals bonding molecular orbital and antibonding molecular orbitals. The bonding molecular orbital having lower energy and is occupied by a pair of electrons (a Lewis base) is called HOMO (Highest Occupied Molecular Orbital) while antibonding molecular orbital having lower energy remains and is unoccupied (a Lewis acid) is called LUMO (Lowest Unoccupied Molecular Orbital) of the compound. HOMO and LUMO are a pair of orbitals which interact most strongly. As they lie at the outermost boundaries of the electrons of a compound, they are together termed as Frontier Molecular Orbital (FMO). The FMO analysis for 5methyl-2-isopropylphenol has been carried out using B3LYP/6-311G (d, p) basis set at DFT with structure of the molecule in singlet excited state and has been shown in Figure-9. In Table-8 energies of molecular orbitals undergoing major transitions and their energy gap $(\Delta \mathrm{E})$ have been presented.

Table 8 : Energy Gap $(\Delta \mathrm{E})$ of major Electronic

Transitions

\begin{tabular}{|c|c|c|}
\hline $\begin{array}{c}\text { LUMO (Energy } \\
\text { ELumo) }\end{array}$ & $\begin{array}{c}\text { HOMO (Energy } \\
\text { Еномо) }\end{array}$ & $\begin{array}{c}\text { Energy Gap ( } \Delta \mathrm{E}) \\
\text { (Euчмо -Eномо) }\end{array}$ \\
\hline $43(0.00368 \mathrm{eV})$ & $40(-0.24692 \mathrm{eV})$ & $0.25060 \mathrm{eV}$ \\
\hline $42(-0.01182 \mathrm{~V})$ & $41(-0.22612 \mathrm{eV})$ & $0.21430 \mathrm{eV}$ \\
\hline $42(-0.01182 \mathrm{eV})$ & $40(-0.24692 \mathrm{eV})$ & $0.23510 \mathrm{eV}$ \\
\hline $43(0.00368 \mathrm{eV})$ & $41(-0.22612 \mathrm{eV})$ & $0.22980 \mathrm{eV}$ \\
\hline $44(0.03532 \mathrm{ev})$ & $40(-0.24692 \mathrm{eV})$ & $0.28224 \mathrm{eV}$ \\
\hline $44(0.03532 \mathrm{ev})$ & $41(-0.22612 \mathrm{eV})$ & $0.26144 \mathrm{eV}$ \\
\hline
\end{tabular}

\section{Global and Local Reactivity Descriptors}

Global chemical reactivity descriptors of a compound like hardness, chemical potential, softness, electronegativity, electrophilicity index as well as local reactivity descriptors have been defined [36-40]. Robert Parr and others [36] proposed that a specific property of a chemical species, the square of its electronegativity divided by its chemical hardness, be taken as defining its electrophilicity index. Electronegativity, an atomic parameter, has long been known to be of great use in chemistry. Electronegativity has been defined as average of electron affinity and ionization potential by Pauling and Mulliken [41]. Robert G Parr and others [38] scrutinized the concept of electronegativity by applying Density Functional Theory (DFT) of Hohenberg and Kohn [42]. In the Hohenberg and Kohn density functional theory of the ground state negative of electronegativity is chemical potential. They observed that electronegativity is the same for all orbitals in an atom or molecule in its ground state. They also demonstrated how electronegativity differences between valence states drive electron transfers between atoms on molecule formation. Hardness refers to resistance to deformation or change and mathematically is half the difference of ionization potential and electron affinity. The minimum value of hardness is zero. Softness is the reciprocal of hardness thus zero hardness constitutes maximum softness [39-40]. Hence, we can say that different global reactive descriptors and energy gap of 
major electronic transitions are helpful to describe the stability and reactivity of a molecule. The calculated values of various reactive descriptors are presented in Table -9. A low value of hardness indicates that 5methyl-2-isopropylphenol is soft and can be easily deformed but a negative value of chemical potential shows that it is quite stable and does not undergo decomposition.

Table 9: Reactive Descriptors of 5-methyl-2-isopropylphenol -values calculated from Euuмо and Еномо

\begin{tabular}{|c|c|c|}
\hline Parameter & Relation & Calculated Value \\
\hline Ionization Energy(I) & $-\mathrm{E}_{\text {HOMO }}$ & $0.22612 \mathrm{eV}$ \\
\hline Electron Affinity(A) & $-\mathrm{E}_{\text {LUMO }}$ & $0.01182 \mathrm{eV}$ \\
\hline Chemical Potential $(\Phi)$ & $\frac{-(I+A)}{2}$ & -0.11897 \\
\hline Absolute Hardness $(\eta)$ & $\frac{(I-A)}{2}$ & 0.10715 \\
\hline Softness(S) & $\frac{1}{\eta}$ & 9.33271 \\
\hline Electronegativity $(\chi)$ & $\frac{(I+A)}{2}$ & 0.11897 \\
\hline Electrophilicity Index $(\omega)$ & $\frac{\Phi^{2}}{2 \eta}$ & 0.066047 \\
\hline Electron Donating Capability $(\omega-)$ & $\frac{(3 I+A)^{2}}{16(I-A)}$ & 0.138925697 \\
\hline Electron Accepting Capability $\left(\omega^{+}\right)$ & $\frac{(I+3 A)^{2}}{16(I-A)}$ & 0.019955697 \\
\hline
\end{tabular}

\section{Electrostatic Potential and Electron Density Surfaces}

Molecular Electrostatic Potential (ESP) at a point in space around a molecule gives information about the net electrostatic effect produced at that point by the total charge distribution (electron + nuclei) of the molecule. ESP helps to correlates electrostatic potential with the dipole moment, electronegativity, partial charge, and chemical reactivity of a molecular system i.e., relative.

Shape, size, charge density, and site of chemical reactivity of a molecule is shown by an electron density isosurface mapped with electrostatic potential. Different colours represent different values of electrostatic potential - region of most negative electrostatic potential is represented by red region, region of most positive electrostatic potential is represented by blue colour and region of zero potential is represented by green colour. Electrostatic potential decreases in the order blue $>$ green $>$ yellow $>$ orange $>$ red. The electron density surfaces and electrostatic potential for 5-methyl-2isopropylphenol was computed using B3LYP/6-311G (d, p) basis set at DFT and are shown in Fig. 10 and Fig. 11, respectively. ESP for molecular orbital 41(HOMO) and molecular orbital-42 ( LUMO) are shown in Fig. 12 and Fig. 13.

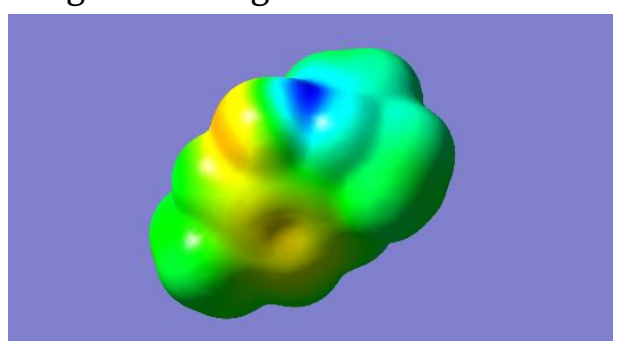

Figure 10: Electron Density of 5-methyl-2isopropylphenol from Total SCF Density (isovalue $=0.0004$;mapped with ESP) 


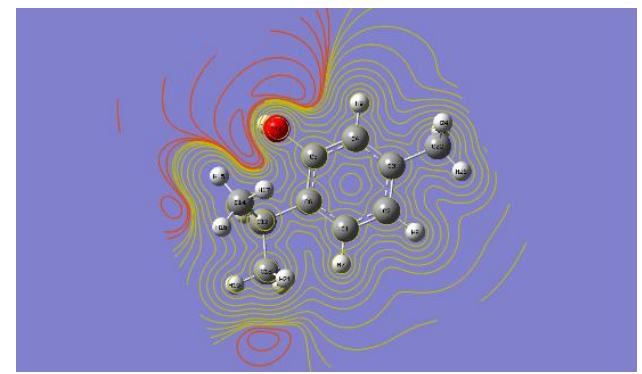

Figure 11: Electrostatic Potential from Total SCF Density (Red- negative charge -yellow-green -bluePositive charge)

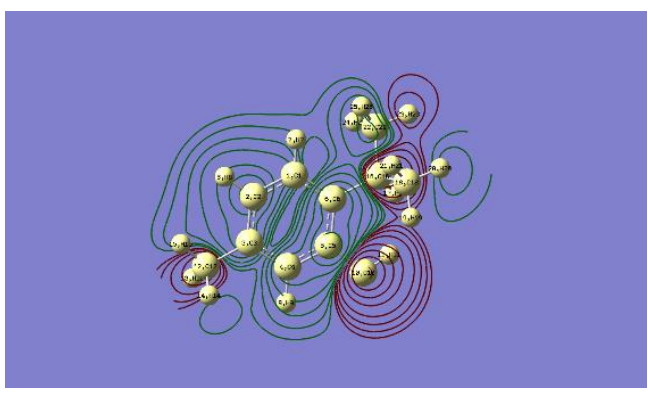

Figure 12: Electrostatic Potential from Total SCF Density (MO-41) $\mathrm{HOMO}$

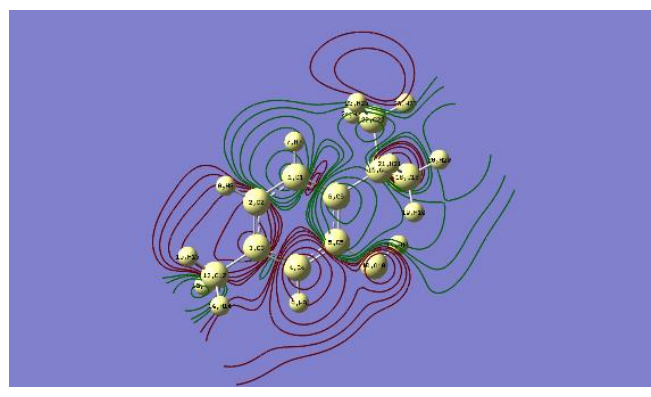

Figure 13: Electrostatic Potential from Total SCF Density (MO-42)

LUMO

\section{CONCLUSION}

To study the structure and reactivity of 5-methyl-2isopropylphenol we carried out an extensive study of optimized geometry, dipole moment, electrostatic potential (ESP), atomic charge distribution, polarizability, hyperpolarizability, chemical potential, electrophilicity, chemical hardness, chemical softness etc. using B3LYP,6-311G (d, p) level of theory. The Electrostatic potential (ESP) and Mulliken population analysis reveals the most possible site for nucleophilic attack is C-5 and for electrophilic attack is O-10. The magnitude of electric dipole $(\mu)$ molecular hyperpolarizability $(\beta)$ shows that the 5-methyl-2isopropylphenol studied has much lesser than that of urea which is used as a standard reference material of prototype molecule hence this molecule is not recommended to be used as a perspective building block for NLO material. A low value of hardness show that this molecule is soft and can be easily deformed but a negative value of chemical potential shows that it is quite stable and does not undergo decomposition.

\section{REFERENCES}

[1]. Amiri, Hamzeh. "Essential oils composition and antioxidant properties of three thymus species." Evidence-Based Complementary and Alternative Medicine 2012 (2012)

[2]. Pandey, Abhay Kumar, Pooja Singh, and Nijendra Nath Tripathi. "Chemistry and bioactivities of essential oils of some Ocimum species: an overview." Asian Pacific Journal of Tropical Biomedicine 4, no. 9 (2014): 682-694.

[3]. Kabouche, Ahmed, Alireza Ghannadi, and Zahia Kabouche. "Thymus ciliatus-the highest thymol containing essential oil of the genus." Natural product communications 4, no. 9 (2009): 1934578X0900400918.

\section{[4]. MArkOvIć, TATjAnA, Paschalina} Chatzopoulou, Jovana Šiljegović, M. Nikolić, Jasmina Glamočlija, Ana Ćirić, and Marina Soković. "Chemical analysis and antimicrobial activities of the essential oils of Satureja thymbra L. and Thymbra spicata L. and their main components." Archives of Biological Sciences 63, no. 2 (2011): 457-464. 
[5]. Ocaña, A., and G. Reglero. "Effects of thyme extract oils (from Thymus vulgaris, Thymus zygis, and Thymus hyemalis) on cytokine production and gene expression of oxLDLstimulated THP-1-macrophages." Journal of Obesity 2012 (2012).

[6]. Bairwa R, Sodha RS, Rajawat BS, "Trachyspermum ammi". Pharmacognosy Review. 2012 Jan; 6(11):56-60.

[7]. Khajeh, Mostafa, Yadollah Yamini, Fatemeh Sefidkon, and Naader Bahramifar. "Comparison of essential oil composition of Carum copticum obtained by supercritical carbon dioxide extraction and hydrodistillation methods." Food chemistry 86, no. 4 (2004): 587-591.

[8]. Miguel, Maria Graça, Custódia Gago, Maria Dulce Antunes, Cristina Megías, Isabel CortésGiraldo, Javier Vioque, A. Sofia Lima, and A. Cristina Figueiredo. "Antioxidant and antiproliferative activities of the essential oils from Thymbra capitata and Thymus species grown in Portugal." Evidence-Based Complementary and Alternative Medicine 2015 (2015).

[9]. Elvers, Barbara. Ullmann's encyclopedia of industrial chemistry. Verlag Chemie, 1991.

[10]. Norwitz, George, Nicole Nataro, and Peter N. Keliher. "Study of the steam distillation of phenolic compounds using ultraviolet spectrometry." Analytical Chemistry 58, no. 3 (1986): 639-641.

[11]. Wade A., Reynolds J. E. F. (1997). Martindalethe Extra Pharmacopoeia. London: The Pharmaceutical Press; 536-537. [Google Scholar] [Ref list]

[12]. Didry, Nicole, Luc Dubreuil, and Madeleine Pinkas. "Activity of thymol, carvacrol, cinnamaldehyde and eugenol on oral bacteria." Pharmaceutica Acta Helvetiae 69, no. 1 (1994): 25-28.

[13]. Mahmoud, A-LE. "Antifungal action and antiaflatoxigenic properties of some essential oil constituents." Letters in Applied Microbiology 19, no. 2 (1994): 110-113.

[14]. Tohidi, Behnaz, Mehdi Rahimmalek, Ahmad Arzani, and Helena Trindade. "Sequencing and variation of terpene synthase gene (TPS2) as the major gene in biosynthesis of thymol in different Thymus species." Phytochemistry 169 (2020): 112126.

[15]. Salehi, Bahare, Abhay Prakash Mishra, Ila Shukla, Mehdi Sharifi-Rad, María del Mar Contreras, Antonio Segura-Carretero, Hannane Fathi, Nafiseh Nasri Nasrabadi, Farzad Kobarfard, and Javad Sharifi-Rad. "Thymol, thyme, and other plant sources: Health and potential uses." Phytotherapy Research 32, no. 9 (2018): 1688-1706.

[16]. Li, Yi, Jia-ming Wen, Chuan-jun Du, Su-min $\mathrm{Hu}$, Jia-xi Chen, Shi-geng Zhang, Nan Zhang et al. "Thymol inhibits bladder cancer cell proliferation via inducing cell cycle arrest and apoptosis." Biochemical and biophysical research communications 491, no. 2 (2017): 530-536.]

[17]. Heghes, Simona Codruta, Lorena Filip, Oliviu Vostinaru, Cristina Mogosan, Doina Miere, Cristina Adela Iuga, and Mirela Moldovan. "Essential Oil-Bearing Plants from Balkan Peninsula: Promising Sources for New Drug Candidates for the Prevention and Treatment of Diabetes Mellitus and Dyslipidemia." Frontiers in Pharmacology 11 (2020): 989.

[18]. Tariq, Saika, Saira Wani, Waseem Rasool, Khushboo Shafi, Muzzaffar Ahmad Bhat, Anil Prabhakar, Aabid Hussain Shalla, and Manzoor A. Rather. "A comprehensive review of the antibacterial, antifungal and antiviral potential of essential oils and their chemical constituents against drug-resistant microbial pathogens." Microbial pathogenesis 134 (2019): 103580.

[19]. Schnitzler, Paul. "Essential oils for the treatment of herpes simplex virus infections." Chemotherapy 64, no. 1 (2019): 1-7. 
[20]. Andrade-Ochoa, Sergio, Guadalupe Virginia Nevárez-Moorillón, Luvia E. Sánchez-Torres, Manuel Villanueva-García, Blanca E. SánchezRamírez, Luz María Rodríguez-Valdez, and Blanca E. Rivera-Chavira. "Quantitative structure-activity relationship of molecules constituent of different essential oils with antimycobacterial activity against Mycobacterium tuberculosis and Mycobacterium bovis." BMC complementary and alternative medicine 15, no. 1 (2015): 1-11.

[21]. Frisch, M. and Clemente, F., 2009. Gaussian 09, Revision A. 01 , Revision A. 01, MJ Frisch, GW Trucks, HB Schlegel, GE Scuseria, MA Robb, JR Cheeseman, G. Scalmani, V. Barone, B. Mennucci, GA Petersson, H. Nakatsuji, M. Caricato, X. Li, HP Hratchian, AF Izmaylov, J. Bloino, G. Zhe.

[22]. Kemp, William. Organic spectroscopy. Macmillan International Higher Education, 2017.

[23]. Silverstein, R.M. and Bassler, G.C., 1962. Spectrometric identification of organic compounds. Journal of Chemical Education, 39(11), p.546.

[24]. Socrates, G., 2004. Infrared and Raman characteristic group frequencies: tables and charts. John Wiley \& Sons.

[25]. Champagne, Benoît, Pierre Beaujean, Marc De Wergifosse, Marcelo Hidalgo Cardenuto, Vincent Liégeois, and Frédéric Castet. "Quantum Chemical Methods for Predicting and Interpreting Second-Order Nonlinear Optical Properties: From Small to Extended $\pi-$ Conjugated Molecules." In Frontiers of Quantum Chemistry, pp. 117-138. Springer, Singapore, 2018.

[26]. Lescos, Laurie, Sebastian P. Sitkiewicz, Pierre Beaujean, Mireille Blanchard-Desce, Benoît Champagne, Eduard Matito, and Frédéric Castet. "Performance of DFT functionals for calculating the second-order nonlinear optical properties of dipolar merocyanines." Physical Chemistry Chemical Physics 22, no. 29 (2020): 16579-16594.

[27]. Chemla, Daniel Simon, ed. Nonlinear Optical Properties of Organic Molecules and Crystals V1. Vol. 1. Elsevier, 2012.

[28]. Sheldrick, GMi. "shelx97." Program package for the solution and refinement of crystal structures (1997).

[29]. Kleinman, D. A. "Nonlinear dielectric polarization in optical media." Physical Review 126, no. 6 (1962): 1977.

[30]. Politzer, Peter, and Robert S. Mulliken. "Comparison of two atomic charge definitions, as applied to the hydrogen fluoride molecule." The Journal of Chemical Physics 55, no. 10 (1971): 5135-5136.

[31]. Rohatgi-Mukherjee, KK Fundamentals of photochemistry . New Age International, 1978.

[32]. Slade, Desmond, Daneel Ferreira, and Jannie PJ Marais. "Circular dichroism, a powerful tool for the assessment of absolute configuration of flavonoids." Phytochemistry 66, no. 18 (2005): 2177-2215.

[33]. Gupta, R., 2020. Study of spectral and NLO properties of (2E)-1-(2, 4-dihydroxyphenyl)-3(4-hydroxyphenyl) prop-2-en-1-one by DFT. Applied Innovative Research (AIR), 1(3-4), pp.160-170.

[34]. Li, Xing-Cong, Daneel Ferreira, and Yuanqing Ding. "Determination of absolute configuration of natural products: theoretical calculation of electronic circular dichroism as a tool." Current organic chemistry 14, no. 16 (2010): 1678-1697.

[35]. Autschbach, Jochen, Lucia Nitsch-Velasquez, and Mark Rudolph. "Time-dependent density functional response theory for electronic chiroptical properties of chiral molecules." Electronic and Magnetic Properties of Chiral Molecules and Supramolecular Architectures (2010): 1-98. 
[36]. Parr, Robert G., László V. Szentpály, and Shubin Liu. "Electrophilicity index." Journal of the American Chemical Society 121, no. 9 (1999): 1922-1924.

[37]. Chattaraj, Pratim Kumar, Buddhadev Maiti, and Utpal Sarkar. "Philicity: a unified treatment of chemical reactivity and selectivity." The Journal of Physical Chemistry A 107, no. 25 (2003): 4973-4975.

[38]. Parr, Robert G., Robert A. Donnelly, Mel Levy, and William E. Palke. "Electronegativity: the density functional viewpoint." The Journal of Chemical Physics 68, no. 8 (1978): 3801-3807.

[39]. Parr, Robert G., and Ralph G. Pearson. "Absolute hardness: companion parameter to absolute electronegativity." Journal of the American chemical society 105, no. 26 (1983): 7512-7516.

[40]. Parr, Robert G., and Pratim K. Chattaraj. "Principle of maximum hardness." Journal of the American Chemical Society 113, no. 5 (1991): 1854-1855.

[41]. Mulliken, Robert S. "A new electroaffinity scale; together with data on valence states and on valence ionization potentials and electron affinities." The Journal of Chemical Physics 2, no. 11 (1934): 782-793.

[42]. Hohenberg, Pierre, and Walter Kohn. "Inhomogeneous electron gas." Physical review 136, no. 3B (1964): B864.

\section{Cite this article as :}

Raksha Gupta, " A Theoretical Study of 5-methyl-2isopropylphenol (Thymol) by DFT", International Journal of Scientific Research in Science and Technology(IJSRST), Print ISSN : 2395-6011, Online ISSN : 2395-602X, Volume 8, Issue 3, pp.812-830, May-June-2021. Available at doi : https://doi.org/10.32628/IJSRST2183182 Journal URL : https://ijsrst.com/IJSRST2183182 